九病虫研会報 $56 ： 66-71(2010)$

Kyushu Pl. Prot. Res. 56 : 66-71 (2010)

\title{
油脂を主成分とする気門封鎖剤や展着剤の噴霧による 防虫ネットの侵入防止効果向上
}

\author{
溝辺真 \\ （宮崎県総合農業試験場）
}

Barrier effect of insect-proof nets coated with adjuvants or spreaders. Makoto Mizobe (Miyazaki Agricultural Experiment Station, Sadowara, Miyazaki 880 - 0212, Japan)

0. $4 \mathrm{~mm}$ 目ネットに代わる微小害虫の侵入防止技術として, $0.8 \mathrm{~mm}$ 目ネットにマシン油や展着 剂を噴霧する方法を室内試験や小規模の野外試験で検討した。油脂を主成分とする気門封鎖剂や いくつかの展着剤を所定の濃度に希釈し， $0.8 \mathrm{~mm}$ 目ネットに噴霧すると, タバココナジラミは ネットに付着した薬液に捕捉され，ネットを通過できなかった。また，同様にマシン油の原液を $0.8 \mathrm{~mm}$ 目ネットに噴霧する方法の侵入防止効果を黄色粘着板への誘殺数により検討したところ, ネットのみの平均誘殺数が 98.2 頭であったのに対し, マシン油を噴霧した場合の平均誘殺数は 0.5 頭となり, $0.4 \mathrm{~mm}$ 目ネットの平均誘殺数 6.0 頭と同等の侵入防止効果が認められた。マシン油 の原液処理はワタアブラムシやヒラズハナアザミウマに対しても, 同様の効果が認められた。さ らに，マシン油の原液処理の効果持続期間について検討したところ，降雨のないガラス室内では, 処理131日後においてもタバココナジラミに対して処理直後とほとんど変わらない効果が認めら れた。

Key words : Aphis gossypii, Bemisia tabaci, Frankliniella intonsa

緒

\section{言}

施設栽培の果菜類では, 薬剤抵抗性を獲得したタバ ココナジラミBemisia tabaci (Gennadius) やミナミ キイロアザミウマThrips palmi Karny などの微小害 虫が大きな問題となってきた（松井，1995; 河合, 2001). 特に近年は, タバココナジラミが媒介するト マト黄化葉巻病ウイルス Tomato yellow leaf curl virus（TYLCV）に代表される虫媒ウイルスが発生し, ウイルスのベクターとしても警戒する必要がでてきて いる（加藤, 1999 ; 本多, 2005 ; 真壁, 2006)。さら に, タバココナジラミでは, 2006年にタバココナジラ ミバイオタイプ Qの発生が確認され (Ueda and Brown, 2006), タバココナジラミバイオタイプBに 有効であった多くの薬剤に対して感受性が低下してい ることが明らかになり（松浦，2006；樋口，2006；小 林, 2007 ; 井園, 2008), ますます防除が難しくなっ ている。

このような状況の中で, 特にTYLCVによるトマト 黄化葉巻病の防除に扔いては, 媒介虫の夕バココナジ ラミの防除が薬剤のみでは困難であったことから, 媒
介虫をハウス内に侵入させない手段として $0.4 \mathrm{~mm}$ 目 以下の防虫ネットが有効であることが明らかにされた (松浦ら, 2005)。また, 八ウス内への夕バココナジラ ミの進入経路が調查され，側面だけでなく，谷部から の侵入防止対策の重要性も指摘されている（杖田・田 口, 2006)。

しかし， $0.4 \mathrm{~mm}$ 目以下の防虫ネットを設置すると 八ウス内の温度上昇が避けられず, 植物の栽培や農業 者の作業環境の面で決して好ましい状態とは言えない (三原・石田，2005）。そのため， $0.4 \mathrm{~mm}$ 目ネットの 代替技術の開発が望まれている。

代替技術の 1 つとして, 防虫ネットの侵入抑制効果 を向上させる方法が考えられる。例えば，金城・松井 （1994）はネットに殺虫剂を含有させる方法により, 侵入防止効果が向上することを報告している。また， 実用新案公報の中には，ネットに粘着物質を付着させ る方法が記載されている（公開実用新案公報：実開平 4 -117586)。

しかし, 前者の技術は薬椷抵抗性が発達したタバコ コナジラミでは効果の安定性の面で不安があることや, 後者の技術は害虫に対する付着力を高めると, 塵や埃, 
ハウスビニルなど付着して欲しくないものも付着して しまうことが懸念される。

松田ら（1995）や溝辺（2007）は, タバココナジラ ミの防除に界面活性剂の 1 種であるオレイン酸ナトリ ウムを主成分とする気門封鎖剂が有効であると報告し ている。そこで, 防虫ネットの侵入防止効果向上の手 段として，界面活性剂を主成分とする展着剂や油脂を 主成分とする気門封鎖剂を防虫ネットに付着させ，防 虫ネット上で，気門封鎖による殺虫効果や侵入防止効 果が期待できるかを検討したので，その結果について 報告する。

\section{材料および方法}

\section{1. 水溶液処理（試験 1）}

界面活性剂を主成分とした展着剂やマシン油等を希 釈した水溶液を防虫ネットに噴霧することによる侵入 防止効果を確認するため以下の室内試験を行った。

供試虫は2004年に宮崎県西都市のピーマン圃場から 採取したタバココナジラミバイオタイプQを室内累代 飼育したものを用いた。また，防虫ネットの処理薬剤 として, 第 1 表に揭げる 2 つの油脂を主成分とする気 門封鎖剂（マシン油，脂肪酸グリセリド）と 4 つの展 着剂を使用した。

なお，これらの剂の選定については，予備試験を 行った気門封鎖剂の中から，実用場面のコストを考慮 し, 安価なマシン油の効果を検討することとし, 同じ 油脂由来の気門封鎖剂である脂肪酸グリセリドを比較 のために含めた。また, 展着剤については, 主成分の 界面活性剂が非イオン系, 㓌イオン系, 陽イオン系に
大別されるため，それぞれから代表的な展着剤を選定 した。なお，展着剤の多くが複数の界面活性剂の混合 物であるため, 1 種類の界面活性剂の成分の効果を確 認するため,トリトンX-100を対照とした。

供試薬剂はいずれも市販品を使用し, 所定濃度に水 道水で希釈して試験に用いた。また，水道水のみの区 を設けるとともに，防虫ネットに何も噴霧しない区を 無処理区とした。防虫ネットは， $0.8 \mathrm{~mm}$ 目ネット (日本ワイドクロス (株) 製：サンサンネット SL2700）を使用した。防虫ネットを $5 \mathrm{~cm} \times 5 \mathrm{~cm}$ に切 断したものに, 所定濃度に希釈した各薬剂をハンドス プレー（(株）フルプラ製：スウイング500）により， ネットから約 $30 \mathrm{~cm}$ の距離から約 10 回噴霧 (約 $8 \mathrm{ml})$ した。噴霧量は薬液がネットに十分付着する量（第 2 図右程度の付着量）をあらかじめ確認して, 決定した。 なお, 薬液のうち多くはネットの周辺に落下し, ネッ トに付着したのは噴霧した量の一部である。薬剤を処

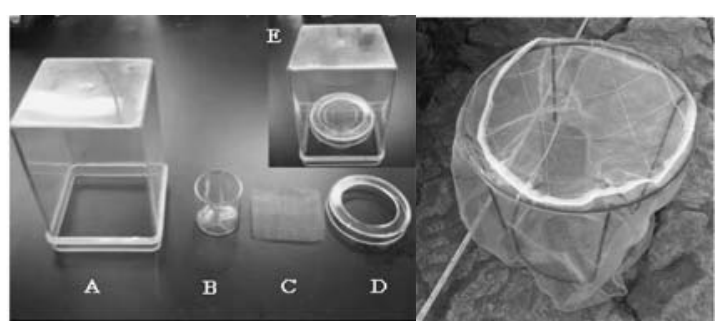

第 1 図使用した実験器具 (左：試験 1 , 右：試験 $2,3,4)$. A : プラスチック製容器, B : ガラス容器, $\mathrm{C}$ ：防虫ネット, D：シャーレ蓋（中央穴あき， E：A$\mathrm{D}$ を組み立てた状態, 右図 : 円筒形の鉄枠に袋状にした 防虫ネットを上から被せた試験器具.

第 1 表 防虫ネットに対する各薬剤処理がタバココナジラミの通過率に及ぼす影響（試験 1 ）

\begin{tabular}{|c|c|c|c|c|c|c|}
\hline 一般名 ${ }^{\text {a) }}$ & 商品名 & 濃度 & $\begin{array}{c}\text { 供試個体数 }{ }^{\mathrm{b})} \\
(\mathrm{A})\end{array}$ & $\begin{array}{l}\text { 通過個体数 }{ }^{b)} \\
(B)\end{array}$ & $\begin{array}{c}\text { 通過率 }(\%) \\
(\mathrm{B} / \mathrm{A})\end{array}$ & $\begin{array}{l}\text { ネット上の } \\
\text { 捕捉率 } \\
(\%)\end{array}$ \\
\hline マシン油 & ラビサンスプレー & 100倍 & $61.0 \pm 5.3$ & 0 & 0 & 91.2 \\
\hline 脂肪酸グリセリド & サンクリスタル乳剂 & 300倍 & $65.7 \pm 7.2$ & 0 & 0 & 92.4 \\
\hline $\begin{array}{l}\text { ポリオキシエチレンア } \\
\text { ルキルエーテル }\end{array}$ & ミックスパワー & 3, 000倍 & $64.0 \pm 5.5$ & 0 & 0 & 97.2 \\
\hline $\begin{array}{l}\text { ポリオキシエチレンメ } \\
\text { チルポリシロキサン }\end{array}$ & まくぴか & 3, 000倍 & $55.7 \pm 1.9$ & 0 & 0 & 90.8 \\
\hline $\begin{array}{l}\text { アルキルベンゼンスル } \\
\text { ホン酸ナトリウム }\end{array}$ & ニーズ & 1,000 倍 & $60.0 \pm 2.1$ & 0 & 0 & 95.5 \\
\hline $\begin{array}{l}\text { ポリナフチルメタンス } \\
\text { ルホン酸ジアルキル } \\
\text { ジメチルアンニウム }\end{array}$ & サブマージ & 3,000倍 & $69.0 \pm 7.5$ & 0 & 0 & 97.0 \\
\hline トリトンX-100 & トリトンX-100 & 1,000 倍 & $59.7 \pm 6.6$ & 0 & 0 & 92.9 \\
\hline 水道水 & - & - & $43.0 \pm 4.6$ & $33.0 \pm 4.9$ & 76.7 & 1.9 \\
\hline 無処理 & - & - & $55.7 \pm 11.6$ & $43.0 \pm 6.7$ & 77.2 & 0 \\
\hline
\end{tabular}

a）展着剤は主成分のうち代表的な1成分を記載した.

b) 数值は平均值 \pm 標準誤差. 


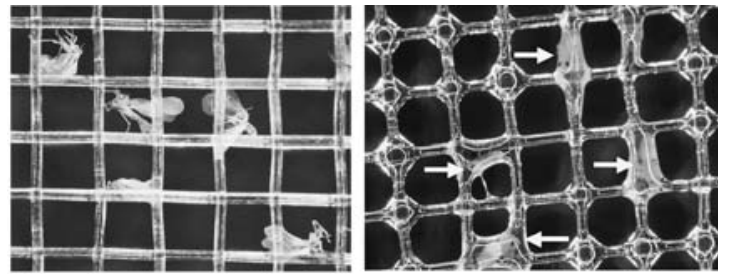

第 2 図 ネット上に捕捉されたタバココナジラミ（左： 試験 1 のマシン油100倍処理, 右 : 試験 2 のマシン油原 液処理)。いずれも2 日間風乾した後で撮影. なお，写 真右はマシン油の液中にタバココナジラミが取り込まれ ており，矢印はその箇所を示す.

理したネットは，速やかに実験に供試し，ネットが薬 液で濡れた状況で実験を開始した。

実験は第 1 図に示す容器を用いて, 次のとおり行っ た。直径 $27 \mathrm{~mm}$, 深さ $28 \mathrm{~mm}$ の円筒形のガラス容器 (第 1 図, B ) に，供試虫を30７0頭前後放飼し，ガ ラス容器の上部を薬剤処理した防虫ネット（第 1 図,

C）で蓋をした。防虫ネットとガラス管の間に隙間が できないように直径 $55 \mathrm{~mm}$ のプラスチック製シャーレ の中央部に直径 $40 \mathrm{~mm}$ の穴をあけたもの（第 1 図,

D）を防虫ネットの上にかぶせた。防虫ネットを通過 した供試虫を把握するために, これら実験器具全体を 直方体 $(6.5 \times 6.5 \times 10 \mathrm{~cm})$ のプラスチック製の容器 (第 1 図，A）で覆った（第 1 図， E)。供試虫放飼 48 時間後に防虫ネットを通過した個体数と通過できな かった個体を調査した。なお, 試験は各薬剤 3 反復で 実施した。

\section{2. マシン油原液処理（試験 2 ）}

試験 1 で検討した薬剂について, 予備試験で原液処 理の効果を確認したところ, 水溶液処理と比較して効 果の持続性の面で有利であると考えられた。そこで, 原液処理を想定した場合に最も安価なマシン油につい て, タバココナジラミ, ワタアブラムシ, ヒラズハナ アザミウマに対する原液処理の効果を検討した。防虫 ネットは $0.8 \mathrm{~mm}$ 目ネット(試験 1 と同じ製品), $0.4 \mathrm{~mm}$ 目ネット（日本ワイドクロス（株）製：サン サンネットSL4200）を使用した。いずれのネットも 袋状に加工したものを直径 $44 \mathrm{~cm}$, 高さ $40 \mathrm{~cm}$ の円筒形 の金属染（アイリスオーヤマ（株）製：ボールプラン タースタンド）に被せた試験器具を使用した（第 1 図 右)。試験は $0.8 \mathrm{~mm}$ 目ネットにマシン油を噴霧する区 (以下 $0.8 \mathrm{~mm}$ 目ネット+マシン油処理), マシン油を 噴霧しない $0.8 \mathrm{~mm}$ 目ネットと $0.4 \mathrm{~mm}$ 目ネットの合計 3 区を設けた。 $0.8 \mathrm{~mm}$ 目ネットへのマシン油の噴霧 は2009年 2 月10日に電動噴霧器を用いて行った。同日,
各区ともネット内に黄色粘着板（アリスタライフサイ エンス（株）製：ホリバー）を吊し，タバココナジラ ミの多発したトマト栽培のハウス $(6 \mathrm{~m} \times 15 \mathrm{~m})$ に搬 入した。ハウス内には $10 \mathrm{~m} \times 0.8 \mathrm{~m}$ の畧（株間 $50 \mathrm{~cm}$, 2 条植でトマトを栽培）があり，その周囲に 18 個（3 区 $\times 6$ 反復）を並べ，位置による誘殺数の影響が少 なくなるように各区の配置は 1 反復目の順番を 6 回繰 り返した。2009年 2 月24日に黄色粘着板を回収し, 夕 バココナジラミの誘殺数を調査した。

同様の試験をアブラムシ類およびアザミウマ類を対 照に行った。この試験では, ワタアブラムシ Aphis gossypii Gloverとヒラズハナアザミウマ Frankliniella intonsa (Trybom) が多数寄生したキュ ウリの株をハウス内に持ち込み試験を行った。試験は 2009年 3 月10日から同年 3 月 13 日にかけて実施した。 なお,この試験では, $0.8 \mathrm{~mm}$ 目ネットのマシン油処 理と0. $8 \mathrm{~mm}$ 目ネットのみの 2 区を比較した。試験は 3 反復で行った。

\section{3. マシン油原液処理の効果持続期間（試験 3 ）}

降雨の影響がない条件におけるマシン油原液処理の 効果持続期間を検討するため, 試験 2 と同じ $0.8 \mathrm{~mm}$ 目ネットと円筒形の金属枠を用いて試験を行った。 2008年 9 月19日に試験 2 と同様の方法でマシン油を処 理した後，枠内に黄色粘着板を設置し，ガラス室 $(8$ $\mathrm{m} \times 20 \mathrm{~m} ）$ に搬入した。比較のために $0.8 \mathrm{~mm}$ 目ネッ トのみの区を設けた。黄色粘着板は 2008 年 9 月 30 日， 10月15日，10月31日，12月 1 日に新しいものと交換し た。また，タバココナジラミをガラス室内で常時発生 させるため, ハウス内でナスの苗を40～80株を維持し た。なお，試験は 6 反復で実施した。

\section{4. マシン油原液処理による温度への影響 (試験 4)}

試験は試験 2 と同じ金属製の円筒枠を用い,

$0.4 \mathrm{~mm}$ 目, $0.8 \mathrm{~mm}$ 目, $0.8 \mathrm{~mm}$ 目のマシン油原液処 理，無被覆の 4 区を設け，ガラス室内に静置して内部 の気温を測定した。2009年 3 月 4 日 $14: 30 〜 15: 30$ ま で10分間隔で温度計測機器（(株）ティアンドデイ： おんどとり jr， SRTR-52L）により金属枠内部中央の 地上 $20 \mathrm{~cm}$ の高さの気温を測定した。

\section{結果}

\section{1. 水溶液処理（試験 1 ）}

マシン油，脂肪酸グリセリド，そして界面活性剤を 主成分とする展着剂 4 剂を所定濃度に希釈して防虫 ネットに処理したところ通過率は $0 \%$ となった（第 1 表)。また，界面活性剤であるトリトンX-100につい 
ても，通過率は 0 \%であった。通過できなかったタバ ココナジラミのほとんどはネット上に捕捉され（第 2 図左)，薬剤を処理したいずれの区でもネット上での 捕捉率は $90 \%$ 以上であった (第 1 表)。

一方，無処理抢よび水道水処理の通過率はともに約 $77 \%$ で, ネット上への捕捉率は無処理区で $0 \%$, 水道 水処理区で $2 \%$ とほとんど捕捉された個体は認められ なかった (第 1 表)。

\section{2. マシン油原液処理（試験 2 ）}

防虫ネットにマシン油を原液処理したときのタバコ コナジラミの侵入量を第 3 図左に示した。 $0.8 \mathrm{~mm}$ 目 ネットのみの場合, ネット内の誘殺数は黄色粘着板あ たり平均 98.2 頭であったが, $0.8 \mathrm{~mm}$ 目ネットにマシ ン油を処理すると誘殺数は 0.5 頭と有意に減少し (ANOVA 後, Tukey多重検定, $P<0.05$ ), $0.4 \mathrm{~mm}$ 目ネットの区（誘殺数 6.0 頭）との間に有意差は認め られなかった。なお, 試験 1 と同様にマシン油を処理 した防虫ネット上で多数のタバココナジラミが死亡し ていた（第 2 図右）。

ワタアブラムシの誘殺数は $0.8 \mathrm{~mm}$ 目ネットのみで 15.0頭だったのに対し，マシン油処理では 0 頭であっ た（第 3 図中央）。ヒラズハナアザミウマの誘殺数は $0.8 \mathrm{~mm}$ 目ネットのみで 16.3 頭に対し, マシン油処理 では 0 頭であった（第 3 図右）。いずれもマシン油を 処理した区では，ネットのみの区と比較して誘殺数が 有意に減少した $(t$ 検定, $P<0.05)$ 。

\section{3. マシン油原液処理の効果持続期間（試験 3 ）}

0. $8 \mathrm{~mm}$ 目ネットにマシン油原液処理を行うことに よる夕バココナジラミの侵入防止効果の持続期間につ いて，結果を第 2 表に示した。 $0.8 \mathrm{~mm}$ 目ネットのみ
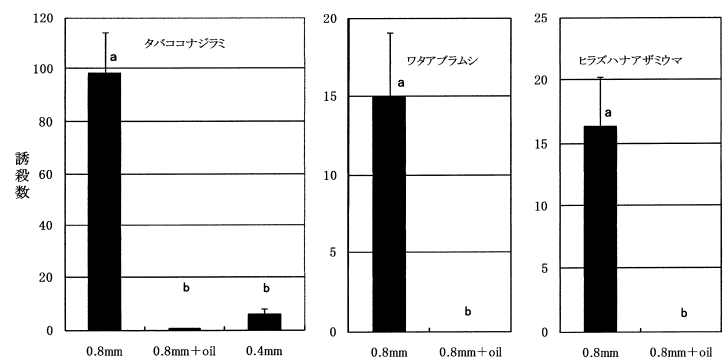

第 3 図防虫ネットに対するマシン油原液処理の侵入防 止効果（試験 3 ). 棒グラフの縦線は標準誤差を示す。 グラフ内の異なる文字間には $5 \%$ 水準で有意差あり（夕 バココナジラミ：ANOVA 後, Tukey多重検定, ワタア ブラムシおょびヒラズハナアザミウマ: $t$ 検定).

$0.8 \mathrm{~mm}: 0.8 \mathrm{~mm}$ 目ネット区, $0.8 \mathrm{~mm}+$ oil $: 0.8 \mathrm{~mm}$ 目 ネット+マシン油処理区, $0.4 \mathrm{~mm} ： 0.4 \mathrm{~mm}$ 目ネット区.
では, 誘殺数は $174.8 \sim 1,658.3$ 頭と多数の侵入が認め られたが, マシン油を処理した区では, 誘殺数は 0.8 ４. 0 頭と極めて少なく, 調査したどの期間でもネッ トのみの誘殺数の概ね $1 \%$ 程度に抑制した。

また，処理110日〜131日後においても，ネットのみ の誘殺数が平均 451.0 頭に対して, $0.8 \mathrm{~mm}$ 目ネット+ マシン油区では4.0頭であり, その効果は处理直後と ほとんど変わらなかった。

\section{4. マシン油原液処理による温度への影響 (試験 4 )}

それぞれの処理区に扔ける14:30～15:30の平均気温 は， $0.4 \mathrm{~mm}$ 目ネットが約 $38.2^{\circ} \mathrm{C} ， 0.8 \mathrm{~mm}$ 目ネットが 約 $33.9^{\circ} \mathrm{C}, 0.8 \mathrm{~mm}$ 目ネットのマシン油原液処理が約 $33.6^{\circ} \mathrm{C}$ ，無被覆が $31.1^{\circ} \mathrm{C}$ であった (第 4 図)。

\section{考察}

本試験では $0.4 \mathrm{~mm}$ 目ネットの代替手段として $0.8 \mathrm{~mm}$ 目ネットに薬剤を処理する方法を検討した。 試験 1 の結果では，マシン油や界面活性剂を主成分と する展着剤を所定濃度に希釈しネットに噴霧すること で，タバココナジラミに対し高い侵入防止効果が認め られた (第 1 表)。試験時の観察から, 薬液が処理さ れたネット上をタバココナジラミが通過する際に, 体 の一部が薬液に触れると, 虫体は徐々に表面張力の低 い薬液に取り込まれ, 最終的には体全体が取り込まれ て、気門封鎖による窒息死を起こしているものと考え られた。また, 試験 2 のマシン油原液処理についても 同様の現象が観察された。

一方, 水道水処理の場合は, 夕バココナジラミが触 れても，簡単に離れることができ，そのままネットを 通過しており, 無処理区との通過率はほとんど変わら なかった (第 1 表)。これは, 水の表面張力が高いた め, タバココナジラミを捕捉することができないこと に加え，気門封鎖の効果もないことが原因と考えられ た。

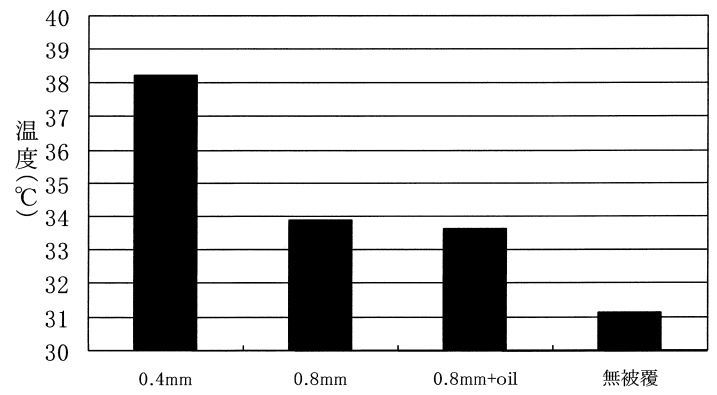

第 4 図防虫ネット被覆およびマシン油処理が気温上昇 に及ぼす影響（試験 4 ）。各区の略称は図 3 と同様. 
第 2 表 マシン油原液処理による夕バココナジラミの侵入防止効果持続期間（試験 3 )

\begin{tabular}{|c|c|c|c|c|c|c|c|c|}
\hline \multirow{3}{*}{ 区名 } & \multicolumn{8}{|c|}{ 調查期間 / 処理後日数 } \\
\hline & $9 / 19 \sim 9 / 30$ & $9 / 30 \sim 10 / 15$ & $10 / 15 \sim 10 / 31$ & $10 / 31 \sim 12 / 1$ & $12 / 1 \sim 12 / 10$ & $12 / 10 \sim 12 / 24$ & $12 / 24 \sim 1 / 7$ & $1 / 7 \sim 1 / 28$ \\
\hline & 0～11日後 & 11 26日後 & 26〜 42日後 & 42〜 73日後 & 73〜82日後 & 82～96日後 & 96〜110日後 & 110～131日後 \\
\hline $\begin{array}{c}0.8 \mathrm{~mm} \text { ネット } \\
\text { +マシン油 }\end{array}$ & $\begin{array}{l}0.8 \pm 0.4^{\text {a) }} \\
(0.5)^{\text {b) }}\end{array}$ & $\begin{array}{l}3.8 \pm 0.8 \\
\quad(0.2)\end{array}$ & $\begin{array}{l}3.5 \pm 1.5 \\
\quad(0.3)\end{array}$ & $\begin{array}{l}\text { 4. } 0 \pm 2.1 \\
\quad(0.3)\end{array}$ & $\begin{array}{l}2.5 \pm 0.6 \\
\quad(1.1)\end{array}$ & $\begin{array}{l}\text { 1. } 7 \pm 1.1 \\
\quad(0.5)\end{array}$ & $\begin{array}{l}1.5 \pm 0.4 \\
(0.4)\end{array}$ & $\begin{array}{l}\text { 4. } 0 \pm 1.7 \\
\quad(0.9)\end{array}$ \\
\hline $0.8 \mathrm{~mm}$ ネット & $\begin{array}{l}174.8 \pm 34.1 \\
\quad(100)\end{array}$ & $\begin{array}{c}1,658.3 \pm 660.7 \\
(100)\end{array}$ & $\begin{array}{c}1,274.3 \pm 315.5 \\
(100)\end{array}$ & $\begin{array}{c}1,149.8 \pm 280.1 \\
(100)\end{array}$ & $\begin{array}{l}228.3 \pm 59.8 \\
\quad(100)\end{array}$ & $\begin{array}{l}360.5 \pm 77.0 \\
\quad(100)\end{array}$ & $\begin{array}{l}349.5 \pm 89.5 \\
(100)\end{array}$ & $\begin{array}{c}451.0 \pm 127.6 \\
\quad(100)\end{array}$ \\
\hline
\end{tabular}

a) 数值は平均值 \pm 標準誤差. $\quad$ b) 括弧内の数值は $0.8 \mathrm{~mm}$ 目ネットのみの数值を 100 としたときの数値.

試験 1 において, 界面活性剂を主成分とする展着剂 やマシン油の水溶液処理では, 処理液が乾いてしまう とその効果がほとんど認められなくなり，効果の持続 期間は数分から数十分程度であることが観察されてい る。一方，マシン油原液処理の場合，降雨など水によ る流亡がない条件では効果の持続性が認められ，その 効果は処理131日後まで確認された (第 2 表)。その理 由については，原液処理の場合，有効成分であるマシ ン油の含有率が $98 \%$ と高く, 時間が経過しても揮発に よる成分ロスがほとんどないため，マシン油が液体状 態のまま長期間維持されることによるものと考えられ た。

この点は一般的な粘着物質を防虫ネットに処理した 場合との大きな違いであると考えられる。一般的な粘 着物質の場合, 市販の黄色粘着板等のように時間の経 過とともに砂埃あるいは害虫の付着による粘着力の低 下や，それに伴うネット目詰まりが予想される。一方， マシン油原液処理の場合, 砂埃はマシン油の液体の中 に取り込まれるため, 液体の表面は砂埃の影響を受け にくく, 効果の低下が起こりにくいものと考えられ る。

また，この方法は，防虫ネットの侵入抑制よりも， より積極的な侵入防止効果があると言える。それは， 防虫ネットのみの場合, ネットに到達して侵入できな かった害虫は，八ウスの周辺を飛翔し，八ウスの谷部 から侵入したり，周囲の雑草や他のハウスに侵入した りするといった機会が残される。ところが，今回の方 法では, ネットに到達した時点で死亡するため, その 個体の侵入機会は完全に奪われることになる。このこ とは，特にウイルス媒介虫の侵入防止においてはより 重要な意味をもつだろう。

今回の試験から, 室内試験や小規模の野外試験にお いて, マシン油等の処理が防虫ネットの侵入防止効果 を向上させることが明らかとなった。また，本法はハ ウス内温度への影響も小さく (第 4 図), $0.4 \mathrm{~mm}$ 目
ネットの代替手段として, ハウス内環境の改善といっ た点からも実用的な技術と考えられる。しかしながら， 降雨や砂埃が多い実際のビニルハウスでは，どのよう な利用方法が最も効果的であるかについて, 今後はコ ス卜面も含め多方面から検討を重ねていく必要がある。

\section{引用 文 献}

加藤公彦（1999）トマトの新しいウイルス TYLCV. 植物防疫53:308-311.

河合＼cjkstart章（2001）ミナミキイロアザミウマの個体群管 理. 応動昆45：39-59.

金城衣恵・松井正春（1994）殺虫剤含有ネットによる タバココナジラミ防除の可能性. 関東東山病虫研報 $41: 217-221$.

小林政信（2007） コナジラミ類の薬剤感受性の特性. 植物防疫61：21-26.

樋口聡志（2006）熊本県におけるタバココナジラミバ イオタイプ $\mathrm{Q} の$ 発生状況と薬剤の殺虫効果. 今月の 農業50（9）：84-88.

本多健一郎（2005）トマト黄化葉巻病と媒介コナジラ

ミをめぐる最近の研究情勢. 植物防疫59：299-304.

井園佳文 (2008) タバココナジラミBemisia tabaci バイオタイプ Qに対する数種農薬の防除効果. 日植 防研報 9 ：19-24.

真壁貞夫 (2006) 虫媒ウイルス病対策。植物防疫60： 19-21.

松田径央・宮田哲至・高木康至（1995）オレイン酸ナ トリウム液剤の殺虫効果とそのメカニズム。植物防 疫 $49: 50-53$

松井正春（1995）タバココナジラミ新系統（仮称：シ ルバーリーフコナジラミ) の発生とその防除対策. 植物防疫 49:21-24.

松浦 明・田村真理子・志摩五月 (2005) シルバー リーフコナジラミに対する防虫ネットの目合いと侵 入防止効果との関係. 九病虫研会報51：64-68. 
松浦 明 (2006) 宮崎県におけるタバココナジラミバ イオタイプ $\mathrm{Q}$ の発生と防除対策. 今月の農業 50 ( 2 ) : 57-61.

三原順一・石田豊明（2005）トマトの生育に及ぼす育 苗ハウスの防虫網と屋根遮光の影響. 九農研67： 144.

溝辺 真 (2007) 物理的・生物的防除による促成栽培 トマトのタバココナジラミ防除。農業および園芸 $82: 671-676$.
杖田浩二・田口義広（2006） トマト黄化葉巻病の発病 分布とタバココナジラミの施設への進入状況につい て. 関西病虫研報48:23-28.

Ueda, S. and J. Brown (2006) First report of the Qbiotype of Bemisia tabaci in Japan by mitochondrial cytochrome oxidase I sequence analysis. Phytoparasitica $34:$ 405-411.

(2010年 4 月19日受領：8月12日受理) 